\title{
MORPHOMETRIC ANALYSIS AND PRIORITIZATION OF SUB-WATERSHEDS IN NAHRA WATERSHED OF BALAGHAT DISTRICT, MADHYA PRADESH: A REMOTE SENSING AND GIS PERSPECTIVE
}

\author{
Deepak Patle ${ }^{1 *}$ J Himanshu Rao ${ }^{1}$, Snehil Dubey ${ }^{2}$
}

${ }^{1}$ Department of Soil and Water Engineering, College of Agricultural Engineering, JNKVV, Jabalpur, 482004, India

${ }^{2}$ Department of Soil and Water Conservation Engineering, Banaras Hindu University, Varanasi, 221004, India

Received - June 07, 2020; Revision - July 20, 2020; Accepted - August 19, 2020

Available Online - August 25, 2020

DOI: http://dx.doi.org/10.18006/2020.8(4).447.455

\section{KEYWORDS}

GIS

Morphometric Analysis

Prioritization

Remote Sensing

Watershed

\begin{abstract}
In this study, morphometric analysis and prioritization of the eleven sub-watersheds of Nahra watershed, located in the Central-Eastern part of the Balaghat district of Madhya Pradesh, India, was carried out using Remote Sensing (RS) and Geographical Information System (GIS). The morphometric parameters considered for analysis are stream length, bifurcation ratio, drainage density, stream frequency, texture ratio, form factor, circularity ratio, elongation ratio, and compactness coefficient. The Nahra watershed has a dendritic drainage pattern. The highest bifurcation ratio among all the sub-watersheds is 6.667 which indicates a strong structural control on the drainage. The maximum value of circularity ratio and elongation ratio are 0.696 and 0.684 , respectively for the SW8. The form factor values are in the range of 0.181 to 0.368 , which indicates that the Nahra watershed has a moderately high peak flow of shorter duration. The compound parameter values were calculated and a prioritization rating of eleven mini-watersheds in Nahra watershed was carried out. The mini-watershed with the lowest compound parameter value is given the highest priority. The SW8 has a minimum compound parameter value of 4.222 is likely to be subjected to the maximum soil erosion; hence, it should be provided with immediate soil conservation measures.
\end{abstract}

* Corresponding author

E-mail: deepak.patle12@gmail.com (Deepak Patle)

ORCID ID: 0000-0001-9763-6168

Peer review under responsibility of Journal of Experimental Biology and Agricultural Sciences.

Production and Hosting by Horizon Publisher India [HPI] (http://www.horizonpublisherindia.in/).

All rights reserved.
All the articles published by Journal of Experimental Biology and Agricultural Sciences are licensed under a Creative Commons Attribution-NonCommercial 4.0 International License Based on a work at www.jebas.org.

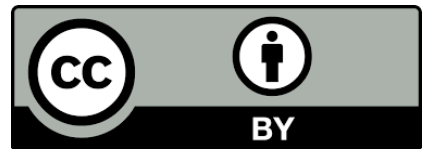




\section{Introduction}

Soil erosion is putting severe threats to human existence. Food and water are the two core pillars of the sustenance of human life on earth. Conversely, population explosion, the congregation of people, availability of limited arable land, and economic imbalance is putting a great burden on food security and water availability (Patil et al., 2016). Providing ample quantity of food, water for drinking and sanitation purposes and energy for a growing world is always a major challenge to science (Sharma et al., 2010; Sharma \& Seth, 2010; Bisen et al., 2019).

A watershed can be defined as a part of landform biophysically defined by the flow of water in it, drained by a current or spatial pattern of currents pointing towards a common exit point or a gathering area lying at a lower elevation (Sharma et al., 2008; Sharma et al., 2012). In the last few decades, watershed management has attained due global recognition for the management of natural resources with significant importance on both environmental sustainability and improvising socio-economic condition of the residing rural population of the watershed (Patle et al., 2017; Patle, 2018; Patle \& Awasthi, 2019a; Patle \& Awasthi, 2019b).

Morphometric analysis refers to the quantitative assessment of characteristics of the earth's surface and any landform unit (Sharma et al., 2013). It is the most preferable method of prioritizing sub-watersheds by measurement of linear, aerial, relief, and gradient of channel network (Nag \& Chakraborty, 2003). Understanding the hydrogeomorphological behavior of watershed is essential in managing natural resources at such scale triggering an in-depth study of discrete watersheds for the progression of an amenable management plan which needs massive data (Tignath et al., 2014). Major numbers of watersheds in India are deprived of the appropriate gauging facility (Gajbhiye et al., 2015). Investigation of morphometric parameters of a watershed represents its attributes that can be valuable in integrating hydrological behavior (Meshram \& Sharma, 2018). Geomorphological and Hydro-geological investigations like morphometric analysis, hypsometric analysis, identification of groundwater potential zones, groundwater management, and environmental assessment can be effectively executed in watersheds as an implementation of the suitable action plan is comparatively easier as that on a provincial level (Rao, 2019; Rao et al., 2019; Awasthi \& Patle 2019).

Over recent years, numerous studies have been performed for prioritization of sub-watershed on the foundation of morphometric parameters (i.e. linear, areal and shape factors) using perspectives of remote sensing and GIS such as Meshram \& Sharma (2015), Sharma et al. (2015), Balasubramanian et al. (2017); Gaikwad \& Bhagat (2018) and Malik et al. (2019).
Further, Meshram \& Sharma (2015) employed remote sensing and GIS for the successful accomplishment of morphometric analysis by incorporating Principal Component Analysis (PCA) and consequently prioritizing sub-watersheds of Shakkar river catchment, India. Poongodi \& Venkateswaran (2018) achieved the prioritization of micro-watersheds employing morphometric analysis in Vasishta Sub Basin of the Vellar river of Tamil Nadu in India. Similarly, Arulbalaji \& Padmalal (2020) performed a morphometric analysis to prioritize sub-watersheds of the Cauvery river basin situated in South India using a simple compound parameter approach.

In this study, an effort has been made to assess the morphological parameters of individual sub-watersheds of Nahra watershed using RS and GIS techniques. Furthermore, consequent prioritization of sub-watersheds based on final priority rank was executed to suggest appropriate action strategy for soil and water conservation measures to be established in different sub-watersheds of Nahra watershed. Manual methods of executing morphometric analysis are prone to human error and cumbersome that can create bias in the study thus making the use of GIS in such investigations can help to minimize such errors.

\section{Materials and Methods}

\subsection{Study Area}

Nahra watershed lies between $21^{\circ} 54^{\prime} 00.84$ " \& $21^{\circ} 55^{\prime} 41.49$ " $\mathrm{N}$ latitudes and $80^{\circ} 23^{\prime} 13.74^{\prime \prime}$ to $80^{\circ} 25^{\prime} 52.61^{\prime \prime}$ E longitudes in the centraleastern part of the Balaghat district of Madhya Pradesh state of India. The Nahra nala watershed lies in Wainganga basin whose climate differs from Himalayan sub-tropical to sub-temperate. Total area of the watershed is $35 \mathrm{~km}^{2}$. Watershed receives an annual rainfall of 1295 $\mathrm{mm}$ due to southwest monsoon from the midst of June to the midst of September. The temperature variation is watershed ranges from $43^{\circ} \mathrm{C}$ during summer in May to $8^{\circ} \mathrm{C}$ in winters in December. Figure 1 shows the location map of Nahra watershed.

\subsection{Geo-referencing and delineation of watersheds}

The delineation of Nahra watershed was executed by utilizing toposheet No. $64 \mathrm{C} / 5$ of Survey of India (SOI) on a scale of 1:50,000. The geo-referencing of toposheet was performed so as obtain the watershed boundary of Nahra watershed by digitizing in ArcMap ${ }^{\mathrm{TM}}$ environment. The position of the outlet was set at the confluence point of Nahra river with the Malwara nala. The watershed was further subdivided into 11 sub-watersheds. The categorization of these subwatersheds for delineation was accomplished based on increasing stream order commencing from third-order stream to trunk order stream. The nomenclature of sub-watersheds was given as SW1, SW2, SW3, SW4, SW5, SW6, SW7, SW8, SW9, SW10, and SW11 whose pictorial representation is depicted in Figure 2. 


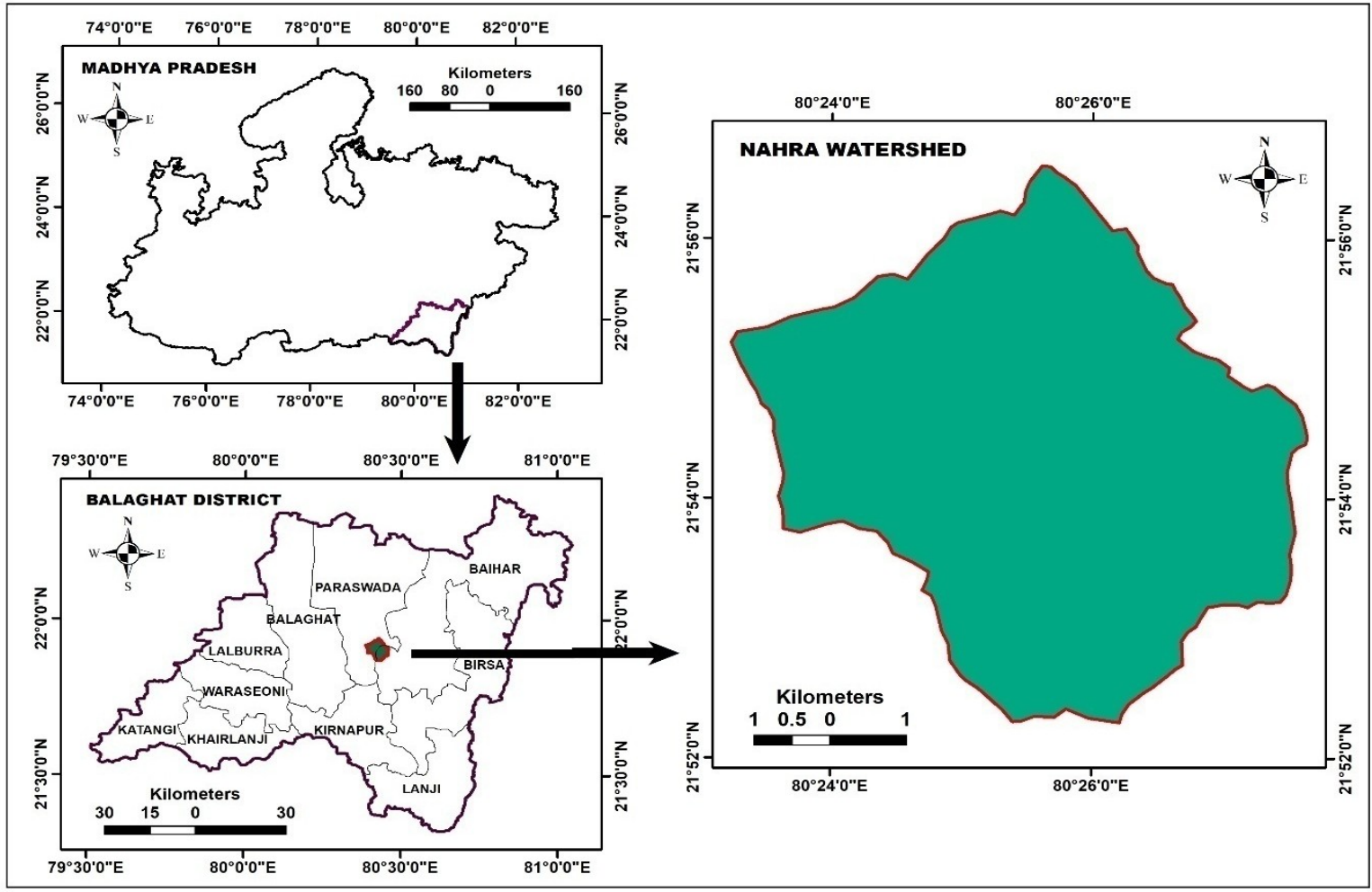

Figure 1 Location map of the Nahra Watershed

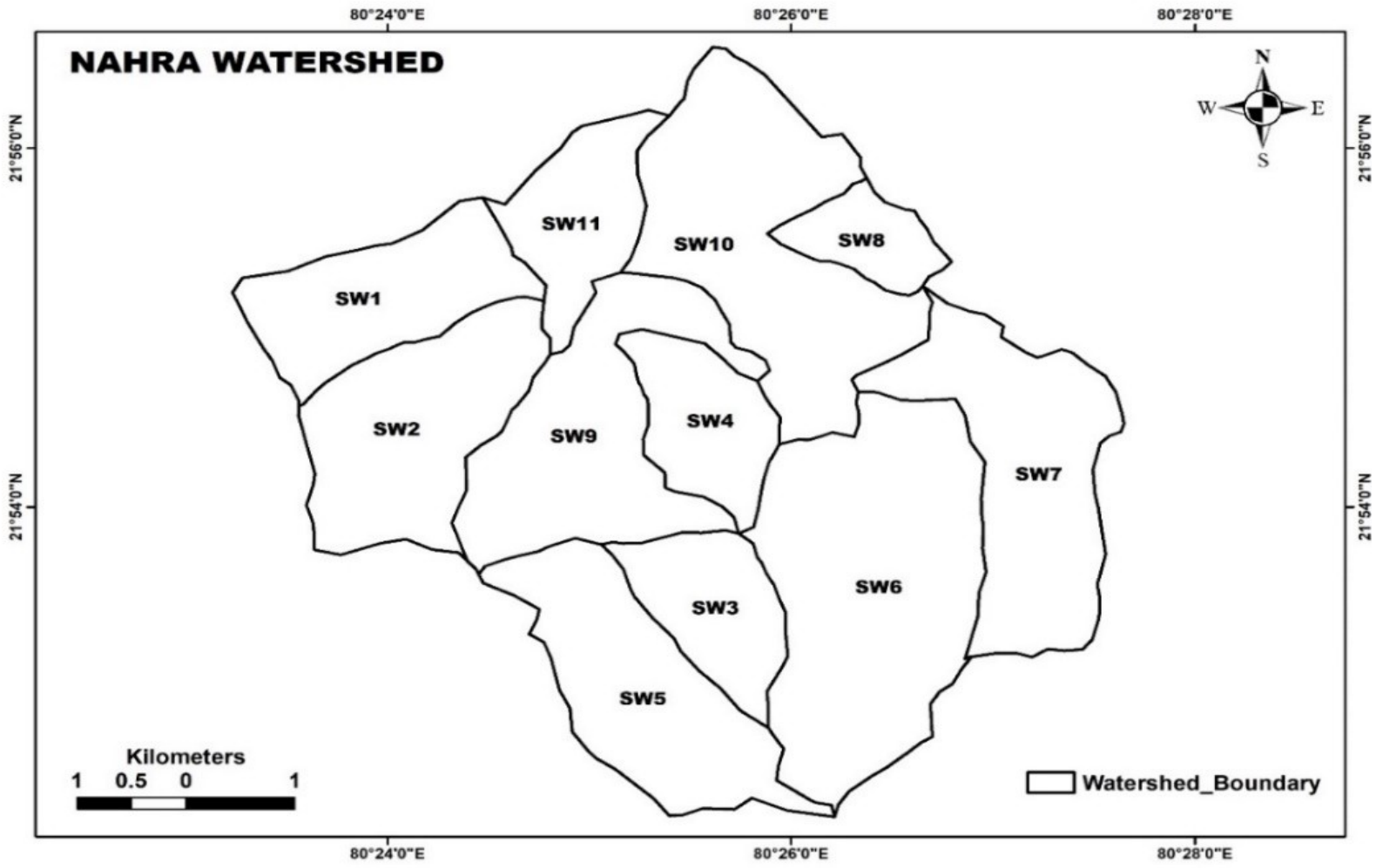

Figure 2. Sub-watersheds of Nahra watershed

Journal of Experimental Biology and Agricultural Sciences http://www.jebas.org 


\subsection{Geomorphologic parameters of watershed}

Geomorphologic characterization is an efficient representation of the geometry and stream channel arrangement in the watershed. Geometry and stream channel system of the watershed requires the estimation of (i) linear phase; (ii) areal phase; and (iii) relief phase of the channel system and contributing ground slopes. The initial two phases (i) and (ii) are planimetric and the third phase looks at the verticalim balances in the drainage basin. The geomorphological parameters of stream network in a watershed are required tounderst and the hydrologic manner of the watershed so that planning and management of its assets could be done effectively. The factors computed in the present study using $\operatorname{ArcMap}^{\mathrm{TM}}$ environment include area $(A)$, perimeter $(P)$, stream order $(u)$, stream length $\left(L_{u}\right)$, and stream number $\left(N_{u}\right)$, which were acquired from the digitized coverage of the drainage network. However, linear/areal factors of the sub-watersheds such as bifurcation ratio $\left(R_{b}\right)$, drainage density $\left(D_{d}\right)$, stream frequency $\left(F_{s}\right)$, texture ratio $\left(R_{t}\right)$, the mean length of overland flow $\left(L_{o m}\right)$, and the shape parameters such as form factor $\left(F_{f}\right)$, circularity ratio $\left(R_{c}\right)$, compactness coefficient $\left(C_{c}\right)$ and elongation ratio $\left(R_{e}\right)$ were calculated by the standard formula as shown in Table 1 .

\subsection{Sub-watershed prioritization}

Prioritization of sub-watersheds was based on morphometric parameters which were assessed according to the linear, aerial, and shape factors. The linear and areal factors are in direct relation to the phenomena of soil erosion taking place in sub-watersheds (Biswas et al., 1999; Sharma et al., 2010; Malik et al., 2019) which allocates the highest value of each parameter as highest priority rank starting from the one which increases gradually for decreasing values of the factors. On the contrary, shape factors possess an inverse relationship concerning soil erosion, hence the parameters with the lowest value are assigned highest priority rank that decreases gradually with increasing value of the parameter (Nooka et al., 2005). Final priority ranking was obtained on the basis of the compound parameter, obtained by taking an average of allocated rankings to different factors of morphometric analysis. The final priority ranking was in direct relationship to the numeric values of a compound parameter such that lowest value of compound parameter was designated highest rank that increases with increasing values of compound parameters.

\section{Results}

The stream order analysis of the Nahra watershed was attained using the spatial analyst tool in ArcMap ${ }^{\mathrm{TM}}$ environment. The drainage network map of Nahra watershed is depicted in Figure 3 showing a dendritic pattern. Investigation of morphometric parameters of each sub-watershed of Nahra watershed was achieved whose numeric values are presented in Table 2 and 3. Furthermore, the succeeding allotment of ranks to morphological parameters is tabulated in Table 4.

Basin length $\left(L_{b}\right)$ for all sub-watersheds of Nahra nala was calculated through the measure tool available in $\operatorname{ArcMap}^{\mathrm{TM}}$ environment. Assessment of basin length indicated that SW6 possessed the highest value of $L_{b}$ (i.e. $4.400 \mathrm{~km}$ ) and was minimal for SW8 (i.e.1.600 km) amidst all the sub-watersheds.

Table 1 Various morphological parameters and formula used for computation

Geomorphologic parameters

Formula

References

\begin{tabular}{|c|c|c|}
\hline Stream order $(u)$ & Hierarchical rank & Strahler (1964) \\
\hline Mean stream length $\left(L_{s m}\right)$ & $\begin{array}{l}L_{s m}=L_{u} / N_{u} \\
\text { where } L_{u}=\text { total length of streams of order } u, N_{u}= \\
\text { total number of stream segments of order } u\end{array}$ & Strahler (1964) \\
\hline Basin length $\left(L_{b}\right)$ & $L_{b}=1.312 A^{0.568}$ & Nooka et al. (2005) \\
\hline Bifurcation ratio $\left(R_{b}\right)$ & $R_{b}=N_{u} / N_{u+1}$ & Schumn (1956) \\
\hline Drainage density $\left(D_{d}\right)$ & $D_{d}=L_{u} / A$ & Horton (1945) \\
\hline Mean length of overland flow $\left(L_{o m}\right)$ & $L_{o m}=1 / 2 \times D_{d}$ & \\
\hline Stream frequency $\left(F_{s}\right)$ & $F_{s}=N_{u} / A$ & Horton (1945) \\
\hline Texture ratio $\left(R_{t}\right)$ & $\begin{array}{l}R_{t}=N_{u} / P \\
\text { where } P=\text { watershed perimeter }(\mathrm{km})\end{array}$ & Horton (1945) \\
\hline Form factor $\left(F_{f}\right)$ & $\begin{array}{l}F_{f}=A / L_{b}^{2} \\
\text { where, } L_{b}=\text { length of basin }(\mathrm{km})\end{array}$ & Horton (1945) \\
\hline Elongation ratio $\left(R_{e}\right)$ & $R_{e}=1.128 A^{0.5} / L_{b}$ & Schumn (1956) \\
\hline Circularity ratio $\left(R_{c}\right)$ & $R_{c}=12.57 \mathrm{~A} / \mathrm{P}^{2}$ & Miller (1953) \\
\hline Compactness coefficient $\left(C_{c}\right)$ & $\mathrm{C}=0.2821 P / A^{0.5}$ & Horton (1945) \\
\hline
\end{tabular}




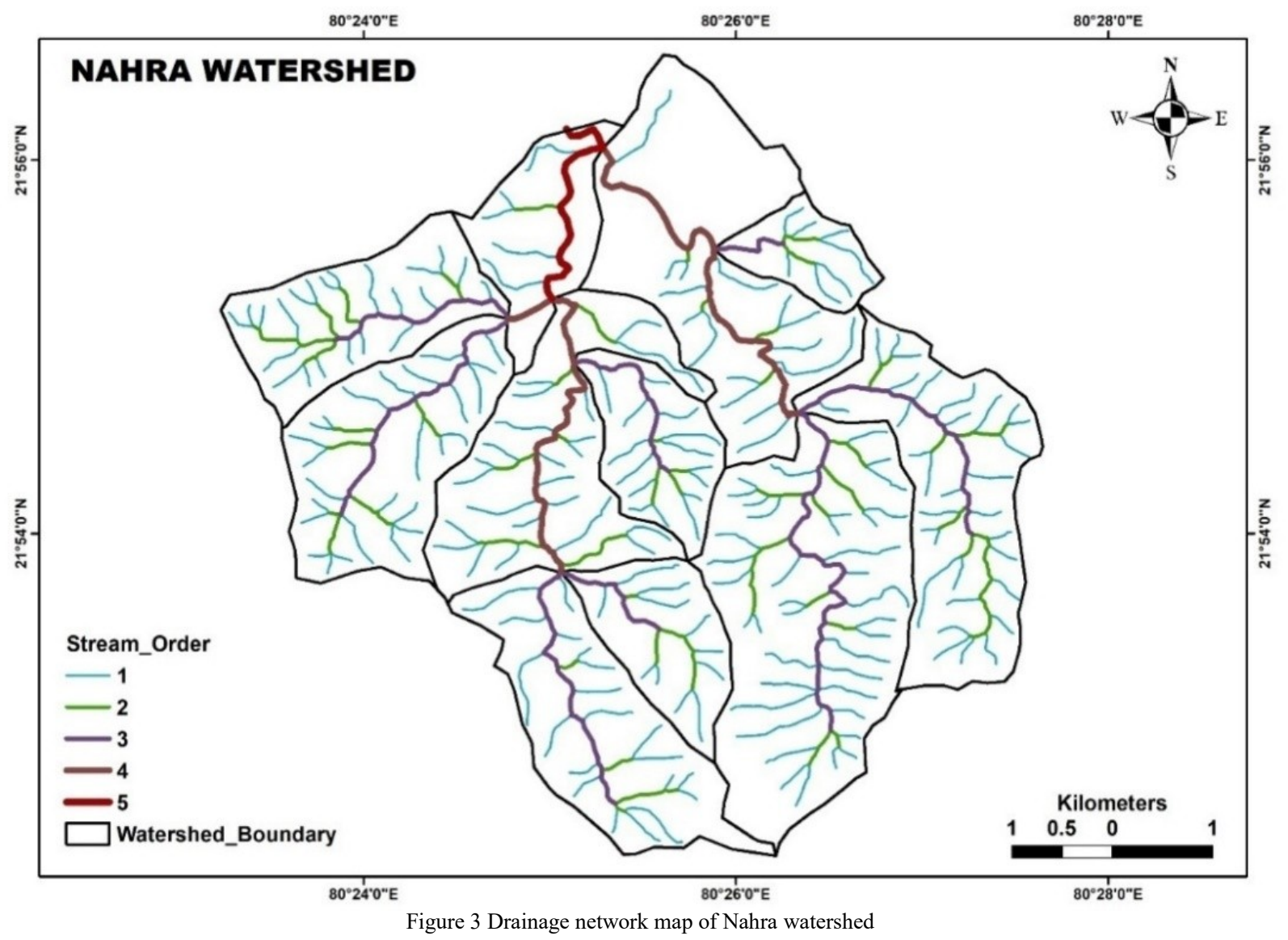

Table 2 Sub-watershed wise morphometric parameters of Nahra watershed

\begin{tabular}{|c|c|c|c|c|c|c|c|c|c|c|}
\hline \multirow{2}{*}{$\begin{array}{l}\text { Sub-watershed } \\
\text { (SW) Name }\end{array}$} & \multicolumn{5}{|c|}{ Number of Stream Order } & \multirow{2}{*}{$\begin{array}{c}\text { Total } \\
\text { Number } \\
\text { of } \\
\text { Streams }\end{array}$} & \multirow{2}{*}{$\begin{array}{l}\text { Total Length of } \\
\text { Stream }(\mathrm{km})\end{array}$} & \multirow{2}{*}{ Drainage Area $\left(\mathrm{km}^{2}\right)$} & \multirow{2}{*}{ Basin Length (km) } & \multirow{2}{*}{$\begin{array}{c}\text { Perimeter of } \\
\text { Basin }(\mathrm{km})\end{array}$} \\
\hline & $1^{\text {st }}$ & $2^{\text {nd }}$ & $3^{\text {rd }}$ & $4^{\text {th }}$ & $5^{\text {th }}$ & & & & & \\
\hline SW1 & 22 & 5 & 1 & 0 & 0 & 28 & 11.026 & 2.600 & 2.750 & 7.442 \\
\hline SW2 & 26 & 6 & 1 & 0 & 0 & 33 & 14.077 & 3.450 & 3.230 & 8.383 \\
\hline SW3 & 11 & 3 & 1 & 0 & 0 & 15 & 6.616 & 1.720 & 2.500 & 5.756 \\
\hline SW4 & 15 & 4 & 1 & 0 & 0 & 20 & 8.258 & 1.670 & 2.400 & 5.670 \\
\hline SW5 & 20 & 4 & 1 & 0 & 0 & 25 & 12.185 & 3.460 & 3.680 & 9.533 \\
\hline SW6 & 32 & 6 & 1 & 0 & 0 & 39 & 16.614 & 6.190 & 4.400 & 11.360 \\
\hline SW7 & 7 & 2 & 1 & 0 & 0 & 10 & 4.397 & 4.000 & 4.200 & 11.119 \\
\hline SW8 & 23 & 6 & 0 & 1 & 0 & 30 & 15.909 & 0.940 & 1.600 & 4.120 \\
\hline SW9 & 39 & 9 & 1 & 0 & 0 & 49 & 24.107 & 3.870 & 4.630 & 12.031 \\
\hline SW10 & 15 & 4 & 0 & 1 & 0 & 20 & 12.899 & 5.080 & 4.260 & 12.480 \\
\hline SW11 & 5 & 1 & 0 & 1 & 1 & 8 & 5.987 & 1.810 & 2.440 & 6.749 \\
\hline
\end{tabular}

Journal of Experimental Biology and Agricultural Sciences http://www.jebas.org 
Table 3 Linear/areal and shape parameters of various sub-watersheds of Nahra watershed

\begin{tabular}{|cccccccccccc|}
\hline $\begin{array}{c}\text { Sub-watershed } \\
\text { (SW) Name }\end{array}$ & \multicolumn{4}{c}{ Linear/ areal parameters } & \multicolumn{5}{c}{ Shape parameters } \\
\hline SW1 & $\mathrm{R}_{\mathrm{b}}$ & $\mathrm{D}_{\mathrm{d}}$ & $\mathrm{F}_{\mathrm{s}}$ & $\mathrm{R}_{\mathrm{t}}$ & $\mathrm{L}_{\mathrm{om}}$ & $\mathrm{F}_{\mathrm{f}}$ & $\mathrm{R}_{\mathrm{c}}$ & $\mathrm{C}_{\mathrm{c}}$ & $\mathrm{R}_{\mathrm{e}}$ \\
\hline SW2 & 4.700 & 4.241 & 10.769 & 3.763 & 0.118 & 0.344 & 0.590 & 1.302 & 0.661 \\
\hline SW3 & 5.167 & 4.080 & 9.565 & 3.937 & 0.123 & 0.331 & 0.617 & 1.273 & 0.649 \\
\hline SW4 & 3.333 & 3.847 & 8.721 & 2.606 & 0.130 & 0.275 & 0.653 & 1.238 & 0.592 \\
\hline SW5 & 3.875 & 4.945 & 11.976 & 3.528 & 0.101 & 0.290 & 0.653 & 1.238 & 0.607 \\
\hline SW6 & 5.600 & 3.522 & 7.225 & 2.622 & 0.142 & 0.255 & 0.479 & 1.446 & 0.570 \\
\hline SW7 & 2.750 & 1.099 & 2.500 & 0.899 & 0.455 & 0.227 & 0.407 & 1.568 & 0.537 \\
\hline SW8 & 1.917 & 16.924 & 31.915 & 7.281 & 0.030 & 0.367 & 0.696 & 1.199 & 0.684 \\
\hline SW9 & 6.667 & 6.229 & 12.661 & 4.073 & 0.080 & 0.181 & 0.336 & 1.725 & 0.479 \\
\hline SW10 & 1.875 & 2.539 & 3.937 & 1.603 & 0.197 & 0.280 & 0.410 & 1.562 & 0.597 \\
\hline SW11 & 2.000 & 3.308 & 4.420 & 1.185 & 0.151 & 0.304 & 0.500 & 1.415 & 0.622 \\
\hline
\end{tabular}

Table 4 Ranking of sub-watersheds on the basis of linear/areal and shape parameters

\begin{tabular}{|c|c|c|c|c|c|c|c|c|c|c|c|c|}
\hline \multirow{2}{*}{$\begin{array}{l}\text { Sub-watershed } \\
\text { (SW) Name }\end{array}$} & \multicolumn{5}{|c|}{ Linear/ areal parameters } & \multicolumn{4}{|c|}{ Shape parameters } & \multirow{2}{*}{ Compound rank } & \multirow{2}{*}{$\begin{array}{l}\text { Priority } \\
\text { ranking }\end{array}$} & \multirow{2}{*}{ Priority category } \\
\hline & $\mathrm{R}_{\mathrm{b}}$ & $D_{d}$ & $\mathrm{~F}_{\mathrm{s}}$ & $\mathrm{R}_{\mathrm{t}}$ & $\mathrm{L}_{\mathrm{om}}$ & $F_{f}$ & $\mathrm{R}_{\mathrm{c}}$ & $\mathrm{C}_{\mathrm{c}}$ & $\mathrm{R}_{\mathrm{e}}$ & & & \\
\hline SW1 & 4 & 4 & 4 & 4 & 8 & 2 & 6 & 6 & 2 & 4.444 & 2 & Very High \\
\hline SW2 & 3 & 5 & 5 & 3 & 7 & 3 & 4 & 8 & 3 & 4.556 & 3 & High \\
\hline SW3 & 7 & 6 & 6 & 8 & 6 & 8 & 3 & 9 & 8 & 6.778 & 7 & Low \\
\hline SW4 & 6 & 3 & 3 & 5 & 9 & 6 & 2 & 10 & 6 & 5.556 & 5 & Medium \\
\hline SW5 & 5 & 7 & 7 & 7 & 5 & 9 & 8 & 4 & 9 & 6.778 & 7 & Low \\
\hline SW6 & 2 & 9 & 8 & 6 & 3 & 4 & 5 & 7 & 4 & 5.333 & 4 & High \\
\hline SW7 & 8 & 11 & 11 & 11 & 1 & 10 & 10 & 2 & 10 & 8.222 & 11 & Very Low \\
\hline SW8 & 10 & 1 & 1 & 1 & 11 & 1 & 1 & 11 & 1 & 4.222 & 1 & Very High \\
\hline SW9 & 1 & 2 & 2 & 2 & 10 & 11 & 11 & 1 & 11 & 5.667 & 6 & Low \\
\hline SW10 & 11 & 10 & 10 & 9 & 2 & 7 & 9 & 3 & 7 & 7.556 & 10 & Very Low \\
\hline SW11 & 9 & 8 & 9 & 10 & 4 & 5 & 7 & 5 & 5 & 6.889 & 9 & Very Low \\
\hline
\end{tabular}

The tectonic and watershed characteristics of a watershed are revealed by $R_{b}$. The value of $R_{b}$ as calculated for each subwatershed showed a variation from 1.875 to 5.667 . High values of $R_{b}$ express mature topography of terrain features producing high runoff potential and least infiltration. Such behavior is expected in terrain features predominant in steep sloping rock strata with narrow valleys circumferential by ridges. Regions with lower $R_{b}$ are areas with less structural control. Such fluctuations in $R_{b}$ for all sub-watersheds are identified to be diversified in plentiful phases of geomorphic evolution and topographic variations.
Areal factors of morphometric parameters taken into consideration for the study were $D_{d}, F_{s}, R_{t}$, and $L_{o m} . D_{d}$ and $F_{s}$ possessed a good positive correlation coefficient (i.e. 0.985 ) thus conveying a linear relationship between the two factors such a manner that an increase in the value of one variable shows a gradual increase in other variables. However, in the case of $R_{t}$ and $L_{o m}$ it was -0.703 which indicated an inverse relationship between the two. Sub-watersheds that generate higher values of $F_{s}$ produce more runoff due to numerous streams in the area. SW8 generated highest $F_{s}$ (i.e. 31.915) followed by SW9 (i.e. 12.661) and was least for SW7 (i.e. 
2.500). Data investigation of numerous variations in geologic and climatic circumstances indicates that small vales of $D_{d}$ is positively expected in areas predominant with subsoil topography of high permeability. Such areas do not possess high elevation differences, condensed with dense vegetal cover. Contradictorily, subwatersheds with higher $D_{d}$ is expected where subsoil geology comprises of impermeable particles as weak subsoil topography with sparse vegetation and huge differences in terms of relief aspects. For Nahra nala, SW7 generated lower values of $D_{d}$ indicating maximum infiltration rate due to permeable subsoil material creating a barrier in runoff generation and consequent stream generation in case of heavy rainfalls. On the other hand, SW8 assimilated higher values of $D_{d}$ reflecting minimum infiltration rate thus by creating a scenario of high runoff in the region. High values of $D_{d}$ in sub-watersheds create situations of a dense network of stream channels that aids in prompt disposal of runoff resulting from extreme flood situations.

The length of overland flow $\left(L_{o m}\right)$ for SW8 was least and for SW5 was highest. $R_{t}$ computed for sub-watersheds directed a variation from $0.899 \mathrm{~km}^{-1}$ for SW7 to $0.721 \mathrm{~km}^{-1}$ for SW8. The most important morphometric parameters primarily responsible for defining the shape of watershed i.e. $F_{f}, R_{c}, C_{c}$, and $R \mathrm{e}$ were calculated for each sub-watershed of Nahra nala. The values of the aforementioned shape factors of morphometric analysis are displayed in Table 3. $F_{f}$ ranged from 0.181 to 0.367 . Watersheds with higher values of $F_{f}$ from 0.7854 are perfectly circular and if this value falls below 0.7854 then they are elongated in shape. Numeral value of $F_{f}$ tending towards unity generate peak flows of shorter duration and those moving away from unity generate lower peak hydrographs with flatten peak having a short duration. For Nahra watershed, $F_{f}$ varied from 0.181 to 0.367 depicting shapes of all inherent sub-watersheds as elongated on which if a high intensity and long duration rainfall occurs, then the subsequent hydrograph generated would be subdued in terms of its peak and the total duration for successful commencement of a flood hydrograph will also be high. Fluctuations in values of $R_{c}$ are due to numerous factors such as stream length, stream frequencies, geological materials, land use/land cover, relief aspects and slope of the basin. $R_{c}$ for different sub-watersheds of Nahra nala differed from 0.336 to 0.696 suggesting that the drainage system is structurally confined. $R_{e}$ started from 0.479 to 0.661 expressing elongated watershed shape and high relief producing steep slope.

The final priority rankings for sub-watershed prioritization was carried out by initially allocating rankings to different morphometric parameters in such a manner that all those factors which are in linear relation with soil erosion susceptibility were given high ranks and those parameters showing inverse relationship were assigned lower ranks for high parameter values. Thus based on the value of the compound parameter as obtained by the ranking of individual priority rankings for morphometric parameters, prioritization of sub-watersheds in Nahra nala was executed. The obtained results showed that all suitable soil and water conservation measures should be adopted heading from SW8 to SW1 and so on based on their respective priority rankings.

\section{Discussion and Conclusions}

The present study makes use of remote sensing and GIS techniques for morphometric analysis and consequent prioritization of subwatersheds in Nahra watershed of Wainganga River basin in Balaghat district of Madhya Pradesh state of India. The morphometric attributes of various sub-watersheds reveal their relative qualities for hydrologic response of the Nahra watershed. Linear and areal parameters are in direct relation with phenomena of soil erosion whereas it is completely inverse in case of shape factors (Biswas et al., 1999; Nooka et al., 2005; Thakkar \& Dhiman, 2007; Sharma et al., 2010; Malik et al., 2019). The consequences of morphometric investigation indicated that subwatersheds SW8 and SW1 were highly prone to soil erosion and should be taken up first for the execution of appropriate soil and water conservation and management measures for soil erosion control and safeguard the land from further erosion in the study region.

\section{Conflict of interest}

Authors would hereby like to declare that there is no conflict of interests that could possibly arise.

\section{References}

Arulbalaji P, Padmalal D (2020) Sub-watershed Prioritization Based on Drainage Morphometric Analysis: A Case Study of Cauvery River Basin in South India. Journal of the Geological Society of India 95(1): 25-35.

Awasthi MK, Patle D (2019) Water Harvesting in Kharif Fallow for Augmenting Ground Water Recharge. 4th International Conference on Soil and Water Resources Management for Climate Smart Agriculture, Global Food and Livelihood Security. SCSI, New Delhi at NASC, New Delhi, India. Page No.94.

Balasubramanian A, Duraisamy K, Thirumalaisamy S, Krishnaraj S, Yatheendradasan RK (2017) Prioritization of subwatersheds based on quantitative morphometric analysis in lower Bhavani basin, Tamil Nadu, India using DEM and GIS techniques. Arabian Journal of Geosciences 10:552.https://doi.org/10.1007/s12517$017-3312-6$

Bisen S, Choudhary P, Awasthi MK, Patle D (2019) Kharif Fallow Utilization for Groundwater Recharge. International Journal of Current Microbiology and Applied Sciences 8(12):284-290. 
Biswas JS, Sudhakar S, Desai VR (1999) Prioritisation of subwatersheds based on Morpometric analysis of drainage basin: A Remote Sensing and GIS approach. Journal of Indian Society of Remote Sensing 22(3): 155-167.

Gaikwad R, Bhagat V (2018) Multi-criteria watershed prioritization of Kas Basin in Maharashtra (India): AHP and influence approaches. Hydrospatial Analysis 1(1):41-61

Gajbhiye S, Sharma SK, Tignath S (2015) Development of geomorphological erosion index for Shakker watershed. Journal of Geological Society of India 86: (361-370)

Horton RE (1932) Drainage basin characteristics. Transactions American Geophysical Union 14:350-361. https ://doi.org/10.1029/TR013 i001p 00350

Horton RE (1945) Erosional development of streams and their drainage basins: hydro physical approach to quantitative morphology. Geological Society of America Bulletin 5: 275-370.

Malik A, Kumar A, Kandpal H (2019) Morphometric analysis and prioritization of sub-watersheds in a hilly watershed using weighted sum approach. Arabian Journal of Geosciences 12(4): 118.

Meshram SG, Sharma S K (2018) Application of principal component analysis for grouping of morphometric parameters and prioritization of water shed. In: Singh VP, Yadav S, Yadav R (Eds)Hydrological Modeling, Select proceedings ICWEES-2016 (Springer). Pp. 447-458.

Meshram SG, Sharma SK (2015) Prioritization of watershed through morphometric parameters: a PCA-based approach. Applied Water Science 7:1505-1519

Miller VC (1953) A quantitative geomorphic study of drainage basin characteristics in the Clinch Mountain area, Varginia and Tennessee, Project NR 389042, Technical Report 3, Columbia University, Department of Geology, ONR, Geography Branch, New York.

Nag SK, Chakraborty S (2003) Influence of rock types and structures in the development of drainage network in hard rock area. Indian Society of Remote Sensing 31(1):25-35. https ://doi.org/10.1007/BF030 30749

Nooka RK, Srivastava YK, Venkateswara RaoV, Amminedu E, Murthy KSR (2005) Check dam positioning by prioritization of microwatersheds using SYI model and morphometric analysis Remote sensing and GIS perspective. Journal of Indian Society of Remote Sensing 33(1): 25-38.

Patil RJ, Sharma SK, Tignath S, Sharma APM (2016) Use of remote sensing, GIS and $\mathrm{C}^{++}$for soil erosion assessment in Shakker river basin, India. Hydrological Sciences Journal 62(2): 217-231. http://dx.doi.org/10.1080/02626667.2016.1217413
Patle D, Awasthi MK, Sikarwar P, Shrivastava RN, Tiwari YK (2017) Investigation on water table behaviour in Tikamgarh, Madhya Pradesh. JNKVV Research Journal 51(2):168-173.

Patle D (2018) Effect of Conservation Structures on Groundwater Recharge in Tikamgarh District, Madhya Pradesh. M.Tech. Thesis submitted to the Department of Soil and Water Engineering, Jawaharlal Nehru Krishi VishwaVidyalaya, Jabalpur. https://krishikosh.egranth.ac.in/handle/1/5810108990

Patle D, Awasthi MK (2019a) Past Two Decadal Groundwater Level Study in Tikamgarh District of Bundelkhand. Journal of the Geological Society of India 94(4): 416-418.

Patle D, Awasthi MK (2019b) Groundwater Potential Zoning in Tikamgarh District of Bundelkhand Using Remote Sensing and GIS. International Journal of Agriculture, Environment and Biotechnology 12(4): 311-318

Poongodi R, Venkateswaran S (2018) Prioritization of the microwatersheds through morphometric analysis in the Vasishta Sub Basin of the Vellar River, Tamil Nadu using ASTER Digital Elevation Model (DEM) data. Data in brief, 20: 1353-1359.

Rao JH (2019) Water Footprint Assessment of Agriculture in Banjar River Watershed. Un published M.Tech Thesis submitted to JNKVV Jabalpur.

Rao JH, Hardaha MK, Vora HM (2019) The Water Footprint Assessment of Agriculture in Banjar River Watershed. Current World Environment 14(3): 476 - 488

Schumn SA (1956) Evolution of drainage systems and slopes in badlands at Perth Amboy, New Jersey. Geological Society of America Bulletin 67: 597-646.

Sharma SK, Gajbhiye S, Patil RJ, Tignath S (2016) Hypsometric analysis using Geographical Information System of Gour river watershed, Jabalpur, Madhya Pradesh, India. Current World Environment 11(1): 56-64.

Sharma SK, Gajbhiye S, Tignath S (2015) Application of principal component analysis in grouping geomorphic parameters of a watershed for hydrological modeling. Applied Water Science 5:89-96

Sharma SK, Rajput GS, Tignath S, Panday R (2010) Morphometric Analysis and prioritization of Watershed using GIS. Journal of Indian Water Resources Society, 30(2): 33-39.

Sharma SK, Seth NK (2010) Use of Geographical Information System (GIS) in assessing the erosion status of watersheds. Scifronts A journal of multiple Science (4):77-82. 
Sharma SK, Pathak R, Suraiya S (2012) Prioritization of subwatersheds based on morphometric analysis using remote sensing and GIS technique. JNKVV Research Journal 46(3): 407-413.

Sharma SK, Tignath S, Gajbhiye S, Patil RJ (2013). Use of Geograpical Information System in Hypsometric analysis of Kanhiya Nala Watershed. International Journal of Remote Sensing and Geosciences 2(3):30-35.

Sharma SK, Tignath S, Mishra SK (2008) Morphometric analysis of Drainage basin using GIS approach. JNKVV Research Journal 42(1):91-95.

Strahler AN (1964) Quantitative geomorphology of drainage basins and channel networks, section 4-II, In Handbook of Applied Hydrology, McGraw Hill Book Company, New York. 4-39.

Thakkar AK, Dhiman SD (2007) Morphometric analysis and prioritization of mini watersheds in Mohr watershed, Gujarat using remote sensing and GIS techniques. Journal of Indian Society of Remote Sensing 35(4):313-321

Tignath S, Kapoor M, Jha M, Sharma SK (2014) Morphometric analysis of part of the Hiranriver, district Jabalpur, M.P., India using remote sensing and GIS. International Journal of Environmental Sciences 5 (1):181-196. 